\title{
Impact of HRA on Productivity of Indian Industries: An Empirical Analysis
}

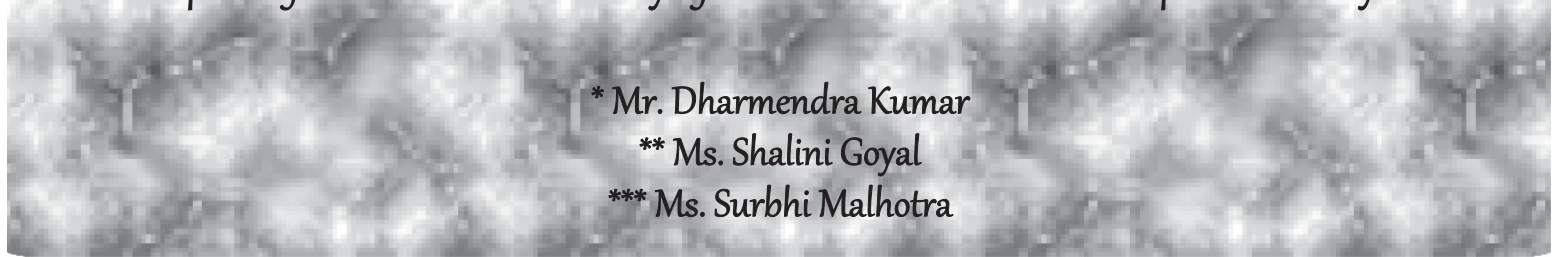

Effulgence

Vol. 12 No. 1

January - June, 2014

Rukmini Devi Institute of Advanced Studies

E-mail : effulgence@rdias.ac.in, Website : www.rdias.ac.in

http://effulgence.rdias.ac.in/user/default.aspX

Abstract

https://dx.doi.org/10.33601/effulgence.rdias/v12/i1/2014/56-61

\begin{abstract}
The idea of human resource valuation and reporting existed for more than half a century. The concept continues to be debated by economic, accounting, and psychology theoreticians universally. The main thrust of accounting human resources is to identify, quantify and report investments made on human resources of an organization that are not presently accounted for under conventional accounting practice. This study critically assesses the concept of HRA in order to unveil its strengths and weaknesses during the era of recession. The study adopted uses secondary data collected through documented texts, journal articles, and other publications. Employees are the most important assets of an enterprise and its success or failure depends on their qualifications and performance. The current accounting system is not able to provide the actual value of employee capabilities and knowledge. This indirectly affects future investments of a company, as each year the cost on human resource development and recruitment increases. Human resource accounting is a direct part of the social accounting and aims to provide information on the evaluation of one of the most important components of the organization, namely human capital.
\end{abstract}

Key Words: HRA, Human Resource, Productivity.

\section{INTRODUCTION}

$\mathrm{I}_{\mathrm{b}}^{\mathrm{n}}$ the month of January 2008, the economy was on boom with sensex riding as high as $21000+$ levels. But as soon as the global downturn \& economic slowdown have arrived, the major sectors generating funds mostly were affected and the problem of unemployment has hit the globe like never before. Suddenly within a couple of months the organizations throughout the world started looking at their employees as liabilities \& not assets. From than to till now, there are heavy layoffs throughout the globe almost in every industry.

With economic bubble bursting out the world is in the cauldron of economic crisis. U.S. employers shed 63,000 jobs in February 2008. Analysis reported that an additional 156,000 jobs had been lost in September. In November 2008 Employers eliminated 533,000 jobs, the largest single month loss in 34 years. For 2008, an estimated 2.6 million U.S. jobs were eliminated. The unemployment rate of US grew to 8.5 percent in March
2009, and there have been 5.1 million job losses till March 2009 since the recession began in December 2007. That is about five million more people unemployed compared to just a year ago. This has become largest annual jump in the number of unemployed persons since the 1940's.

HRA emphasizes the assessment of employee skills, capabilities, competencies and creativities across all the verticals of an organisation. As recession forces consumers to stop investment, producers are forced to go for employee curtailment. Hence, it is a time for the companies to go for innovative methods to deal with economization of staff costs rather than downright downsizing. The coverage of HRA canvasses investments and substitution costs associated with human resources in organisation. Information generated by HRA can be used for a host of managerial \& Strategic decisions like recruitment, turnover, personnel advancement analysis, training and capital budgeting. The perspectives of human resource accounting referred

* Assistant Professor, Delhi College of Technology \& Management, Palwal

**Assistant Professor, Delhi College of Technology \& Management, Palwal

*** Assistant Professor, Rukmini Devi lnstitute of Advanced Studies 
to as the extension of alleviation of sound management practices in an organisation through assessment, determination and communication of facts and figures related to human resources. HRA system attributes the unique way of expressing expansion of accounting standards of comparing investment and returns of human resources in any organisation while simultaneously involving systematic processing of essential information in monetary forms. Human resource accounting system of any organisation is generally inclined to some of the major objectives like sound alleviation of management practices related to human resources in an organisation, supplementing information related to manpower planning dynamics to the management, supporting decision making related to future aspects of human resources from investment point of view, managing effective information system related to human resources, measuring investment occurring on managing ongoing manpower structure, evaluation of return on investment on human resources, recognizing the monetary significance of human resources of organisation, optimum utilisation and allocation of human resources of organisation, establishing investment-worth relationship with respect to investment and actual worth of work of human resources in the organisation, developing management principles related to human resources keeping in view the financial perspective of human resources. This study was conducted in Delhi/NCR region to evaluate whether HRA consideration significantly contribute towards an organisational productivity.

\section{PERSPECTIVE SIGNIFICANCE}

\section{1) Human Resource Accounting: An Emerging Concept}

In today's era of economic turmoil, HRA can be utilized as a tool to retain best talent in the industry and to shed the less efficient manpower. At the same time, the organizations are finding the way hard to implement important strategies while doing layoff so that cost cutting practices may not adversely affect industry operations. In this context, HR Accounting plays a critical role to the problems arising due to recession's impact. Considering the present scenario the human resource were unable to be captured as tangible monetary benefit to company and thus financial accounting could not be made applicable for them. This is when HR Accounting was introduced in IT industry to measure the abilities of human resources.

Knowledge management is emerging as one of the game changing differentiating human resource strategy for today's worldwide contemporary organisations, boosting their probabilities of accomplishing financial and corporate milestones. The changing trends of paradigm shift pushing the need for managers to think for knowledge perspective apart from the concrete consideration of Investment perspective.

Human Resource Accounting is basically an information system that tells management what changes are occurring over time to the human resources of the business. HRA helps in analyzing expenditure on new and substitution of old employees along with the monetary assessment of people in the organisation. The present systems of assessment of employee valuations do not provide a sound platform for the evaluation of monetary substances attached with employee competencies in the organisations. It is a directly observable trend in today's contemporary organisations that employer's expenses on human resources and related areas are consistently increasing with the passage of time. HRA not only supports assessment of human valuation in the organisation but also stimulates top management to safeguard company interests through decision making in the field of manpower planning, employee separation due to various reasons, employee growth analysis and allocation of funds in various activities.

\section{2) Critical Examination of Human Resources}

Human resource is the profit lever of the knowledge economy. Employees of organizations possess knowledge and skills necessary to perform useful functions and achieve the firm's goals and objectives. In essence, the employees contribute in no small measure in generating income for the firm. Also employees interact together and transform other resources of the firm so as to add value. What results from this transformation through "a pool of human resources" is reflected in the profit of the firm. Thus, it is on this basis that human 
resource needs to be accorded a high priority and constantly appraised.

The following are the quantitative measure adopted to assess the human resource effectiveness:

a. Revenue Factor: This is a basic measure of human capital effectiveness and it is the aggregate result of all the drivers of human resource management that influence employees' behavior. This is calculated by taking the total revenue and dividing it by the total headcount of the organization.

b. Expense Factor: This is equally a basic measure of human capital effectiveness. It shows the operating expenses per each employee in the organization. This expense factor is calculated by taking the total operating expenses and dividing it by the total head count of the firm.

c. Income Factor: This measures the operating income of the organization for each employee. This operating income is usually the profit before tax of the company. This factor is computed by taking the profit before tax and dividing it by the total head count of the organization.

d. Production Factor. This measures the production per employee of the organization. This is calculated by taking the total production and dividing it by the total headcount of the organization.

The general trend of analyzing monetary cost associated with establishing a business includes maintaining factual information with respect to corresponding physical objects such as land, equipments, buildings, machinery and tools etc but probably most of the organisations do not consider the aspect of investment associated with manpower set up. Human resource accounting, being the most discussed way of assessing and reporting the monetary measurements linked to human resources in any organisation is still in nascent stage in the industry. Indian industries have also observed the emergence of HRA in recent years with BHEL leading the initiative. The way of conversion of mere knowledge of HRA into utility is gaining momentum with the passage of time. Although considering the aspect of IT industry, presently not much work has been done in IT industry to translate HRA into practicality as these industries have reflected little awareness in making public as shareholders.
Industrial benchmarks are other major obstacles in HRA acceptance $\&$ growth. This signifies that it will require for each industry to establish their standards, which is in turn would be a complicated process in India. This is because still most of the Indian industries are fighting hard for survival, being also hit by recession very badly. One of the major roadblock is the lack of research conducted in analysis of HRA practices in past, nothing much has been done by researchers, posing problems in acceptance of HRA by industry. This is further supported by lack of interest of industries towards identification and assessment of their manpower.

This is quite clear from the nature of human resource accounting practices that it can be a turnaround strategy for large size organisations. But on the other hand, it is a less priority option for small and mid size organisations, for which the economy matters the most. The advantages of HRA leave the top management of organisations in deciding mode to whether to establish an HRA system or not. It is required to establish a investment return relationship for human resources by organisations to recognize the importance of human resources in organisational success. The rising significance and scope of consulting and financial planning services have further added the importance of human resources in industry. The development of human resource accounting is necessary to provide a firm with accurate financial reports to guide its decisions in the developed countries; it is common that companies have formal Human Recourse Accounting reporting system in their report. But, in the developing countries, Human Recourse Accounting reporting system is new concept and it is still in its initial stage. This is not necessary for the Companies in developing countries to disclose Human Recourse Accounting information. In whole world, many companies are making use of HRA as a necessary technique for managing the human resource in a company. The company can project itself in having best practices with superior policies in place. This helps the company's to attract more investments.

3) Competitive Advantages via HRA: Apart from the several competitive advantages of HRA in industries, a few major one's are:

1. The use of human resource accounting helps in finding the real value of manpower in an 
organization. This helps in to finding out the real cost and investment on employees of the company.

2. The HRA helps in maintaining the full records of employees regarding managerial decisions like recruitment .transfers, promotions, appreciations and many other decisions regarding employees of the organization.

3. This helps in managing the quality of the employees of the organization.

4. The HRA helps in fulfill its social responsibility by finding out the reasons of layoffs. Disputes of employee and employers and the quality through resolving the disputes between the manpower of company.

5. It helps to increase the morale, loyalty and interest of human resource, the employees work with the integrity with the objectives of the organization.

6. It helps to increase the productivity of employees.

\section{4) Human Resource Accounting in India:}

Human resource accounting is to find out value and cost of human resources. It is used to measure the cost of all human resource planning and other functions of human resource management. Still it finds scope in some companies because it is considered by other companies that it does not have that much importance to show in financial statements of the organizations. In India, still fewer companies are using HRA. It is not compulsory in India. Infosys Technologies and BPL are the leading companies in India, which are using HRA. HRA reports give useful information to the company management, employees and investors. There are various objectives and needs for using the HRA. The companies in India can get various benefits through HRA if they implement it in organization like BPL and INFOSYS like 1. Information for manpower planning, 2. Information for making personnel policies, 3. Utilization of human resources ,4. Proper placements, 5. Increases morale and motivation,6. Attracts best human resources ,7. Designing training and development programs, 8. Valuable information to investors. So these are some objectives and need why these companies have to implement HRA in their organizations.

With these benefits there are some limitations of HRA these can be -The valuation of human assets is based on the assumption that the employees are going to remain with the organization for a specified period. However, this assumption is wrong because employee mobility is very high. The human resource accounting may lead to the dehumanization in the organization. If the valuation is not done correctly or the results of the valuation are not used properly. In the case of financial accounting, there are certain specified accounting standards which every organization must follow. However, there are no standards for HRA. Each organization has its own standards for it. So, there are no uniform standards for it. Therefore, the HRA of two organisations cannot be compared.

There are no specific and clear cut guidelines for 'cost' and 'value' of human resources of an organization. The present valuation systems have many limitations.

The life of a human being is uncertain. So its value is also uncertain

\section{RESEARCH METHODOLOGY}

\section{1) Sample Size}

The respondents in the sample belong to some of the major IT industries located at Delhi/NCR. The nature of the research area made it difficult for the researcher to encompass a larger sample size but for the accuracy of findings, a reasonable sample size of 34 respondents was considered. The sample size constitutes HR professionals of managerial across some of the reputed industries in Delhi/NCR.

\section{2) Sampling technique}

Simple random technique was used to select respondents from various industries, keeping in consideration their interest towards the nature of study.

\section{3) Measures}

Questionnaire containing items associated with parameters of study was developed and provided to 5 experts of relevant area. Following a week long discussion, the questionnaire was decided after eliminating less important items. The introductory section of questionnaire was having informational details 
of the respondents like age, gender, experience, designation etc. In the main section of questionnaire, there were 9 items considered for studying the influence of HRA on an organisational productivity as Know-how $(\mathrm{KH})$, Education $(\mathrm{E})$, Expertise (EX), Occupational Assessments (OA), Psychometric Assessments (PA), Work Related Competencies (WRC), Entrepreneurial Innovativeness (EI), Changeability $(\mathrm{CH})$, and Productivity Contribution (P).

\section{4) Research Objectives}

The existing literature on Human Resource Accounting clearly displays the fact that nothing much have been done till now in this area and lot of research work is require to be done in this particular field. In India especially, the turbulent issue is in nascent stage with its practical acceptance only being in certain selective industries like BHEL. The criticalities of issue and time consumption are some of the major barriers in this aspect despite the fact that it is a highly sought issue for HR managers in industry. This research is done with the purpose of filling this gap of literature.

The major research objective of this research study is to find out the possibility of any significant impact of potential contributors of Human Resource Accounting on productivity of employees, which in turn justifies the secondary objective of this research study of discussing the need of HRA in today's contemporary organisations.

\section{5) Data Analysis \& Findings}

SPSS 15 was used to conduct correlation study between various parameters of HRA to analyse if there exists any relationship between HRA and an organisation's productivity.

The human resource value of any organisation can be assessed on parameters as Know-how, Education, Expertise, Occupational Assessments, Psychometric Assessments, Work Related Competencies, Entrepreneurial Innovativeness, Changeability, and Productivity Contribution. The table of correlations for these variables is as:-

(REFER TABLE 1 HERE)
Know-How, Expertise, Work Related Competencies as $0.419,0.673,0.583$ and specially and noticeably Changeability as 0.843 shows significant level of correlation with productivity contribution. Clearly attributing the significance of human resource value and hence human resource accounting in any organisation. While psychological assessment as 0.281 and entrepreneurial innovativeness as 0.336 also shows considerable influence in productivity of organisation, the adoptability of changes shows highest degree of relationship with organizational productivity.

\section{RESULTS \& DISCUSSIONS}

In a systematic way, this paper presented the accounting treatment for human resources in organizations. First, general costs relating to human resources should be analyzed, considering the possibility of including them as assets in financial statements. Second, we should also pay attention to training costs, and consider them in the same way as other capitalised expenses. Exit costs should also be considered. The expenses are suggested to be recorded as a provision. The applicability of a particular approach depends upon the individual firm's needs and wants. In the industry downturn, while just laying-off the human resource as a measure of cost cutting practices, the organisations can implement HRA practices in order optimise their human resource efficiency by attracting and retaining the efficient manpower and laying-off inefficient and unwanted manpower. By knowing the worth of the human resource, we can just optimize our resources and make our company competitive in this era. If we put our human resource in the accounting form then we can easily understand that what is the actual performance and net worth of the employee, which is quite useful in facing the recession period.

\section{REFERENCES}

1. American Accounting Association Committee of Accounting for Human Resources, Report of the Committee on Human Resource Accounting, 1973.

2. Annaul reports of SAIl from 2002-03 to 2010-11

3. Eric G. Flamholtz: A Model for Human Resource Valuation: A Stochastic Process with ServiceRewards, 1971.

4. Boudreau, J. \& Berger, C. (1985). Decision - 
theoretic utility analysis applied to employee separation and acquisition. Journal of Applied Psychology (70)581-612.

5. European Center for the Development of Vocational Training (1998). Human resource interests and conflicts, Denmark, www. Cedefop.gr.

6. European Commission (1995). Teaching and learning: Towards the learning society of the European Communities, Luxembourg.

7. Gul, A. (1984). An empirical study of the usefulness of human resource turnover costs in Australia Accounting ' firms: Journal of Accounting, organization and Society, 5-11.

8. Sackman, S.A. Flamholtz, E.G \& Bullen, M.L. (1989). Human resource accounting: A state-of-theArt Review. Journal of Accounting Literature, (8),
235-264.

9. Singh A.K. Gupta N. (2008) "Measurement of Human Asset: An empirical Analysis" Indian Journal of Accounting Vol.XXX VIII (2) June PP 13-20.

10. Sackman, S.A. Flamholtz, E.G \& Bullen, M.L. (1989). Human resource accounting: A state-of-theArt Review. Journal of Accounting Literature, (8), 235-264.

11. Steven, H.A. \& Hannie, H. (1993). Accounting for human resources. Manager Auditing Journal (8) (2) 23-27.

TABLE 1 : Correlations

\begin{tabular}{|c|c|c|c|c|c|c|c|c|c|c|}
\hline & & $\mathrm{KH}$ & E & EX & OA & PA & WRC & EI & $\mathrm{CH}$ & $\mathrm{P}$ \\
\hline \multirow[t]{2}{*}{$\mathrm{KH}$} & Pearson Correlation & 1 & .240 & -.139 & .189 & -.015 & .147 & -.111 & -264 & -.143 \\
\hline & Sig. (2-tailed) & & .172 & 434 & .285 & 933 & .406 & .534 & 132 & 419 \\
\hline \multirow[t]{2}{*}{ E } & Pearson Correlation & .240 & 1 & .005 & .022 & .116 & .221 & .090 & -.206 & .192 \\
\hline & Sig. (2-tailed) & .172 & & .980 & .902 & .514 & 209 & 611 & .242 & .277 \\
\hline \multirow[t]{2}{*}{ EX } & Pearson Correlation & -.139 & .005 & 1 & -.180 & -.108 & .032 & .246 & $.401(*)$ & .075 \\
\hline & Sig. (2-tailed) & .434 & .980 & & .308 & .544 & .857 & .161 & .019 & .673 \\
\hline \multirow[t]{2}{*}{$\mathrm{OA}$} & Pearson Correlation & .189 & .022 & -.180 & 1 & .185 & .188 & -.175 & -.028 & $-.373(*)$ \\
\hline & Sig. (2-tailed) & .285 & .902 & .308 & & .294 & .287 & .323 & .875 & .030 \\
\hline \multirow[t]{2}{*}{ PA } & Pearson Correlation & -.015 & .116 & -.108 & .185 & 1 & .239 & -.016 & .060 & -.190 \\
\hline & Sig. (2-tailed) & .933 & .514 & .544 & .294 & & .174 & .927 & .736 & .281 \\
\hline \multirow[t]{2}{*}{ WRC } & Pearson Correlation & .147 & .221 & .032 & .188 & .239 & 1 & $.376(*)$ & -.059 & .098 \\
\hline & Sig. (2-tailed) & .406 & .209 & .857 & .287 & .174 & & .028 & .741 & .583 \\
\hline \multirow[t]{2}{*}{ EI } & Pearson Correlation & -.111 & .090 & .246 & -.175 & -.016 & $.376(*)$ & 1 & .143 & -.170 \\
\hline & Sig. (2-tailed) & .534 & .611 & .161 & .323 & .927 & .028 & & .421 & .336 \\
\hline \multirow[t]{2}{*}{$\mathrm{CH}$} & Pearson Correlation & -.264 & -.206 & $.401(*)$ & -.028 & .060 & -.059 & .143 & 1 & -.035 \\
\hline & Sig. (2-tailed) & .132 & .242 & .019 & .875 & .736 & .741 & .421 & & .843 \\
\hline \multirow[t]{2}{*}{$\mathrm{P}$} & Pearson Correlation & -.143 & .192 & .075 & $-.373(*)$ & -.190 & .098 & -.170 & -.035 & 1 \\
\hline & Sig. (2-tailed) & .419 & .277 & .673 & .030 & .281 & .583 & .336 & .843 & \\
\hline
\end{tabular}

* Correlation is significant at the 0.05 level (2-tailed). 